\title{
O VALOR (DO) CASAMENTO NA AGRICULTURA FAMILIAR
}

\section{VALMIR LUIZ STROPASOLAS}

Secretaria de Estado do Desenvolvimento Rural e Agricultura de Santa Catarina

Resumo: O artigo aborda o questionamento de valores culturais na agricultura familiar e, especificamente, coloca em relevo as diversas representações que vêm sendo construídas por jovens e mulheres em torno da noção de casamento. Para discutir o significado, a importância e as redefinições em curso na categoria casamento, resgatam-se alguns depoimentos feitos por filhas/os de agricultores familiares no âmbito da minha pesquisa de doutorado realizada na região Oeste de Santa Catarina. A partir da análise das representações e das iniciativas da juventude rural, visualiza-se a emergência de conflitos no horizonte das escolhas dos modelos de família e casamento, processo que repercute nos projetos de vida formulados por moças e rapazes e que acarreta um viés de gênero no movimento migratório de jovens.

Palavras-chove: agricultura familiar, juventude, gênero, casamento.

Ao se abordar o significado e a importância do casamento na agricultura familiar e, particularmente, as representações em torno do papel assumido por homens e mulheres no matrimônio, destaca-se a presença feminina. Pelas raízes históricas do campesinato das regiões coloniais do Sul do Brasil, reproduzidas através das gerações de agricultores familiares que se sucederam nesse território, em um processo acelerado de mobilidade social, vem à tona, a partir das representações de membros do grupo doméstico, um padrão cultural que atribui à mãe o papel de realizar a iniciação das filhas no aprendizado que culmina com a realização do casamento, cabendo ao pai a função de balizar os passos dados nessa direção.

Diversos autores enfatizam o casamento como uma das categorias culturais mais importantes para a análise do campesinato. Para Ellen Woortmann, entre camponeses casar não é uma simples questão de escolha individual: "a rigor, não são apenas dois indivíduos que se casam, mas duas famílias que entram em acordo. Trata-se de um affaire de famille".' Diferentemente de outras categorias sociais, o camponês é ou procura ser, de maneira geral, proprietário da terra, dono dos meios de produção, trabalhador; e chefe de família, sendo esta o ator principal. Em que pese a diversidade de manifestações, as formas sociais e trajetórias individuais que possa adquirir, a unidade agrícola familiar 
possui uma característica especial: é organizada como se fosse um trabalhador coletivo. A idéia da subordinação do indivíduo ao todo, representado pela família, pode ser vista nas obras de Boguslaw Galeski. ${ }^{2}$ Importa salientar que, embora se faça referência à família como um ator coletivo, como uma instituição sociocultural e econômica que interage no todo social, ela está longe de se constituir em um 'mundo encantado', sem contradições.

Na verdade, o processo sucessório e, de certa forma, toda a organização do processo de trabalho são enviesados contra a mulher. Nas regiões coloniais em que predomina a agricultura familiar, verifica-se um padrão a respeito da sucessão nas propriedades rurais. Esse padrão comporta variações e exceções, mas são principalmente os filhos homens que herdam a terra, enquanto as mulheres se tornam agricultoras por casamento. ${ }^{3}$

A influência advinda da luta e conquista de direitos por parte dos movimentos de mulheres na sociedade contemporânea, que se expande e adquire especificidade no espaço rural, a partir da organização dos movimentos de mulheres agricultoras, aliada a fatores restritivos na dimensão econômica, entre outros, repercute nos projetos de vida dos membros da agricultura familiar, redefinindo padrões e noções do que deva vir a ser uma família. Se, antigamente, a norma a ser seguida era a constituição de famílias numerosas - simbolizadas particularmente nos retratos encontrados nas paredes ou no imaginário das antigas gerações de descendentes de italiano -, recentemente, a partir de estratégias e iniciativas 'rebeldes' das próprias mulheres, elaboram-se novos conceitos limitando a prole à sustentabilidade da família, cujos indicadores são construídos com a participação decisiva da mãe. ${ }^{4}$

A delimitação de diferentes papéis entre os membros do grupo doméstico camponês e particularmente as representações formuladoras do lugar ocupado pela mulher, na família e no casamento, eram construídas e reproduzidas socialmente a partir de referenciais culturais que legitimavam a ingerência paterna na definição desse processo decisório. Assim, o patrimônio fundiário, a família e o sistema de valores culturais, ao reproduzirem desigualdades e hierarquias entre os gêneros e as gerações, representavam uma unidade indissolúvel no processo de reprodução social do campesinato. Em que medida esses 'blocos' conceituais, em um certo sentido, institucionais, são ainda sólidos nas representações de agricultores, mulheres e jovens? Ou, de outra maneira, até que ponto as visões de mundo rural construídas por mulheres e jovens questionam e desconstroem esse edifício cultural/institucional?

Este artigo aborda os conflitos de valores presentes no seio da agricultura familiar, particularmente colocando em relevo as representações, expectativas e projetos de vida formulados em torno da noção de casamento por filhos/as de agricultores familiares.

\footnotetext{
2 GALESKI, 1975.

${ }^{3}$ Maria Ignez Silveira PAULILO, 2000, p. 4.

${ }^{4}$ PAULILO, 2000 , p. 2, coloca em evidência, na sua pesquisa, a diminuição do número de filhos, fenômeno ocorrido no mundo todo: "Segundo a ONU, o Brasil está entre os países que apresentam uma queda de mais de $40 \%$ na taxa de fertilidade em um período de 20 anos. Esta taxa era de 4,7 nos anos 1970-75 e baixou para 2,7 em 1990-95. Para as áreas rurais do país, Zuleide Araújo TEIXEIRA et al., 1994, mostram que esta taxa também vem caindo. Se, no período de 1980 a 1985, o maior índice era de 6,8 no Norte e o menor, 3,6 no Sul, no período seguinte, 1985/1990, temos, nas mesmas regiões, 6,0 e 3,1, respectivamente. A estimativa para o ano 2000, mantendo-se a ordem das regiões, é de 5,1 e 2,7. Além disso, a diferença entre a taxa de fertilidade total rural e a urbana vem diminuindo. Embora a primeira continue mais alta, segundo Deise SIQUEIRA (1992), a diferença caiu de 3,18 filhos/mulher em 1970 para 2,29 em 1984".
} 


\section{O questionamento de valores na agri-cultura familiar}

Ao questionar a sua condição social no espaço rural, as mulheres podem elaborar estratégias para sair ou para tentar mudar, ou mesmo para se conformar, mas a recusa dessa passividade passa a ser explicitada nos depoimentos, particularmente das moças, seja repensando o casamento e seus valores, seja formulando estratégias vinculadas ao estudo e à migração para a cidade.

Embora pouco explicitados nos relatórios oficiais ou mesmo nos estudos acadêmicos, os recorrentes depoimentos, dos próprios jovens ou mesmo de técnicos e pesquisadores, indicam o descontentamento das moças - mais explícito entre as filhas de agricultores empobrecidos, mas não menos importante entre as filhas de agricultores capitalizados -e sua recusa em casar e constituir família com filhos de agricultores, bem como a sua procura por estudo e trabalho na cidade para 'mudar de vida'. Esse fato vem preocupando os rapazes que permanecem nas comunidades rurais e começa a entrar na pauta das lideranças representativas. Além de pouco estudado, esse fenômeno não tem sido ainda considerado em toda a sua dimensão pelas instituições que trabalham com a agricultura familiar.

A vigência de relações sociais desiguais e excludentes no seio da agricultura familiar é um dos principais fatores responsáveis pela saída das mulheres do campo. Ou, como se refere Pierre Bourdieu, ${ }^{5}$ "os agentes que opõem a mais fraca resistência às forças de atração externas, que percebem mais cedo e melhor que os outros as vantagens associadas à emigração, são os menos ligados objetiva e subjetivamente à terra e à casa pelo fato de serem mulheres, filhos caçulas ou pobres". Trabalho recente da Comissão Econômica para a América Latina e o Caribe (Cepal) ${ }^{6}$ estabelece de maneira explícita essa vinculação entre o viés de gênero dos processos sucessórios e a migração seletiva no campo. Para os interlocutores dessa instituição, a vida no campo é mais atraente para os rapazes que para as moças. Se aqueles herdam terra ou têm apoio para levar adiante atividades produtivas, podem elaborar projetos de vida que são alternativas válidas em relação à emigração para a cidade. Para as moças, entretanto, uma vida como esposa camponesa - conhecendo outras alternativas possíveis - pode ser rejeitada ou objeto de resistência, diante de aspirações de vida em outro meio cultural e ocupacional.

Ao analisar o celibato no espaço rural francês, Bourdieu' coloca em relevo a lógica das relações entre os sexos. Segundo essa lógica, o primado e a supremacia pertencem aos homens, particularmente na gestão dos negócios familiares. Isso indica que o aparecimento de fenômenos anormais revela que o sistema de trocas matrimoniais, em seu conjunto, tem sofrido uma mudança profunda e que é preciso identificar as suas causas essenciais. Para esse autor, decresce a dependência das trocas matrimoniais em relação aos aspectos econômicos ou, mais exatamente, muda de forma: em lugar de a situação na hierarquia social ser definida pelo patrimônio fundiário, é muito mais o estatuto social e mais precisamente o estilo de vida correlato - que aparece como ligado ao casamento. Ao desmoronamento da base econômica do sistema, vincula-se uma verdadeira transformação dos valores. Em primeiro lugar, a autoridade dos antigos, que repousava, em última instância, sobre o poder de deserdar (excluir da herança), enfraquece, parte por razões econômicas, parte sob a influência da educação e de novas idéias. Assim, os pais que quiseram manifestar sua autoridade ameaçando as crianças com o deserdamento,

\footnotetext{
${ }^{5}$ BOURDIEU, 1979, p. 24.

${ }^{6}$ CEPAL, 1996, p. 27.

${ }^{7}$ BOURDIEU, 1962, p. 64 e 65.
} 
provocaram a desagregação de sua família, tendo os jovens partido para a cidade. Isso é verdadeiro sobretudo para as moças, anteriormente presas à casa e constrangidas a aceitar as decisões de seus pais. Com a instrução, a maior parte delas busca um emprego na cidade, recusando o casamento e a vida social vinculados à agricultura.

Ao lado dos valores propriamente rurais, aparecem valores incorporados do mundo urbano e adotados sobretudo pelas mulheres. Mas o êxodo é, essencialmente, resultado do fato de as mulheres serem mais bem preparadas que anteriormente para enfrentar a vida urbana, passando a questionar o que é visto como servidão na vida camponesa. ${ }^{8}$ Menos ligadas à terra que os rapazes, quando providas de um mínimo de instrução indispensável para se adaptar ao mundo urbano, parcialmente liberadas das restrições familiares em razão do enfraquecimento das tradições, mais prontas a adotar os modelos de comportamento urbano, as filhas dos agricultores podem ganhar as cidades mais facilmente que os rapazes.

O desequilíbrio demográfico entre os sexos, uma característica da população agrícola familiar na França, é explicitado por Bernard Roux, ${ }^{9}$ indicando que na faixa etária de 20 a 29 anos (a idade em que normalmente as pessoas se casam) existiam, em 1995, 140 homens para 100 mulheres, fato esse que acentua o celibato masculino. De acordo com esse mesmo autor, em 1979 havia $22 \%$ de indivíduos celibatários com menos de 40 anos, contra 32\% em 1995.

Na Europa Ocidental, o tema do celibato vem preocupando os órgãos públicos e as organizações profissionais agrícolas há muitos anos. Para Ricardo Abramovay, ${ }^{10}$ uma das conseqüências da masculinização do meio rural europeu é a existência em vários países de agências matrimoniais especializadas em procurar esposas para jovens agricultores que não conseguem, em seu meio de origem, formar um novo núcleo familiar. Em nosso caso, o celibato também se apresenta como uma expressão simbólica da crise na ordem social camponesa? Apenas recentemente começa a ser percebido nos trabalhos de pesquisa uma referência ao celibato como uma estratégia, ao mesmo tempo que um problema, na família camponesa, particularmente no Sul do Brasil. Todavia, a literatura tem ressaltado que nas formas sociais camponesas sempre houve um espaço restrito para a expressão das expectativas e valores dos jovens, tendo em vista que os padrões culturais que influenciavam a reprodução social de categorias nucleantes, como o trabalho familiar, - patrimônio da propriedade e o casamento, definiam papéis que subordinavam as aspirações pessoais dos membros da família aos interesses coletivos, cerceando a liberdade e a participação dos jovens no processo decisório. Às moças cabia um papel hierarquicamente inferior, seja no casamento, seja no processo sucessório.

O caráter seletivo dos processos migratórios recentes nas regiões de predomínio de agricultura familiar no Sul do Brasil, e que tem sido apontado como uma tendência de 'masculinização' da população rural, não foi estudado e tem sido pouco citado nos estudos especializados." Os documentos das organizações internacionais de desenvolvimento como o Instituto Interamericano de Cooperação para a Agricultura (IICA), a Organização das Nações Unidas para a Agricultura e a Alimentação (FAO) e a Cepal só recentemente começaram a tocar no assunto. Embora a migração seletiva não seja um fenômeno novo, - que impressiona é não só a ausência de estudos recentes a respeito, mas, sobretudo, a magnitude que ela parece estar assumindo nas áreas de predomínio da agricultura familiar

\footnotetext{
${ }^{8}$ BOURDIEU, 1962, p. 66-67.

${ }^{9}$ ROUX, 1998.

${ }^{10}$ ABRAMOVAY, 1997b, p. 33.

"ABRAMOVAY, 1997a, p. 32-33.
} 
do Sul do País. Mais precisamente, em 1995 havia 5,2 milhões de homens a mais que mulheres na zona rural latino-americana. Nos grupos entre 15 e 29 anos, essa diferença chegava a 1,8 milhão - havendo $12 \%$ a mais de jovens homens. ${ }^{12}$ Uma desproporção mais ou menos semelhante foi encontrada também na pesquisa da Pastoral da Juventude Rural do Rio Grande do Sul: seu universo compõe-se de $53 \%$ de rapazes e $47 \%$ de moças.

A constatação de representações conflituosas de moças e rapazes sobre o que significa o casamento na construção dos seus projetos de vida sugere a abordagem das redefinições em curso nessa instituição (casamento), que assume um papel crucial na reprodução social da agricultura familiar. Em que medida é possível afirmar que casamento e família compartilham do mesmo 'teto' conceitual na atual condição da agricultura familiar? Até que ponto as representações em torno do casamento são consensuais nas gerações atuais?

\section{Os significados do casamento para filhas e filhos de agricultores familiares}

Ao centrar-se o foco nas representações que vêm sendo elaboradas por filhos/as de agricultores familiares, ${ }^{13}$ percebe-se que os jovens redefinem e ampliam a noção de família de forma a contemplar as expectativas e os projetos de vida formulados ou em curso de realização no seu cotidiano; no entanto, sua constituição não desaparece dos planos dos jovens, embora estes visualizem sua consolidação em um prazo mais distante que aquele comumente observado nas gerações precedentes. No que se refere ao casamento, diversos depoimentos coletados indicam que os jovens, sobretudo as moças, vêm se preocupando com o papel tradicionalmente assumido no 'enlace' matrimonial, debruçando a sua atenção sobre as questões que emergem nas relações afetivas e matrimonias.

Há, atualmente, uma visão e uma avaliação positivas da sexualidade no casamento, mas há também a preocupação, principalmente por parte das moças, quanto à infidelidade dos homens. As moças admitem que haja, ainda hoje, nas famílias, na comunidade e na sociedade em geral, um maior controle sobre a sexualidade feminina e uma certa tolerância em relação às atitudes masculinas nesse campo. Referendando, com um certo constrangimento, o menor controle à infidelidade masculina, um rapaz da comunidade rural de Linha Pinheiro Alto ilustra esse fato:

que nem a mulher do interior não tem, vamos supor, tanta... como fosse de sair com outros homens, né? É quase impossível. Agora o homem, daí fica mais, que nem na cidade, porque na cidade também tem isso muito, né? As mulheres que traem os homens. Os homens aqui, mais no interior, seria o homem, sai mais, né?

Ao se abordar essa questão entre as mulheres, percebe-se a emergência de um conflito que não existe apenas entre os gêneros, mas que alcança também as diversas concepções a respeito elaboradas por diferentes gerações femininas na família ou na comunidade:

A gente achava que ela [a mãe] estava até defendendo o cara, porque a gente dizia assim, que a classe masculina estava defendendo ele, mas a classe feminina estava defendendo a

\footnotetext{
12 CEPAL, 1995, p. 8.

${ }^{13}$ Os depoimentos presentes neste artigo são parte integrante da pesquisa de campo feita no âmbito da minha tese de doutorado (Valmir Luiz STROPASOLAS, 2002), realizada com jovens das comunidades rurais da cidade de Ouro, situada na região Oeste de Santa Catarina.
} 
mulher dele. Entende? E aí ela [a mãe] dizia que não, que elas não podiam estar totalmente a favor dela, ou dele, então a gente achava isso muito... sei lá, que tivesse concordando com - lado dele, a gente não gostava disso, porque a gente queria defender a mulher, o lado dela [...], e as mulheres estavam dizendo, estavam criticando ela, criticando as atitudes que ela tomou quando ela soube disso, e daí a gente não concordava muito com isso, com o que o pessoal estava comentando (moça de Linha Pinheiro Alto).

A noção de violência simbólica elaborada teoricamente por Bourdieu é explicitada, com mais facilidade, nos depoimentos das jovens que questionam a reprodução da dominação masculina pelas próprias mulheres agricultoras, ao legitimarem a sua submissão no caso de um adultério. Essa violência, que não se restringe à perpetuação das prerrogativas morais masculinas, pois atinge a dimensão física do relacionamento matrimonial, sobretudo quando algum relato denuncia que o homem 'maltrata a mulher', atinge o auge da deterioração da condição feminina na agricultura familiar nos casos em que se expressa, nas entrelinhas do discurso, uma posição de inferioridade que, ao desqualificar a própria imagem, revela que a baixa auto-estima é um fato (e uma violência) que se reproduz entre as mulheres agricultoras. Vejamos como isso acontece no depoimento de uma jovem:

os homens estão saindo para procurar outras mulheres na cidade. Aqui já é fato. Vários saem e vão procurar outras mulheres na cidade. Eu acho que é porque talvez a mulher daqui esteja muito cansada, muito cansada de tanto trabalhar que ela já não tenha mais disposição, né. Eu acho que é por isso. Daí eles procuram outras mulheres mesmo para... saem fora e procuram outras mulheres. Além delas serem mais bonitas, talvez aquelas que sejam mais atraentes...

Ao analisar os padrões culturais que acabam sendo internalizados pelas mulheres $e$ que contribuem para a continuidade ou o aumento do capital simbólico em poder dos homens, Bourdieu ${ }^{14}$ levanta uma questão bastante instigante: seria o amor uma exceção, a única, mas de primeira grandeza, à lei da dominação masculina, uma suspensão da violência simbólica, ou a forma suprema, porque a mais sutil e a mais invisível, dessa violência? Em um outro contexto, mas pensando sobre o mesmo tema, uma moça de Linha Pinheiro Alto explica o seguinte:

eu percebo o pessoal que está casado, e eles comentam muito que se soubesse como era não tinha casado. Não sei porque isso, talvez falta se demonstrar o amor, falta demonstrar coisas assim. É bem difícil de entender esta parte.

Essa é também a angústia de diversos pesquisadores que procuraram se debruçar sobre essa questão de difícil entendimento. A mesma jovem busca explicações no campo afetivo masculino e complementa:

enquanto os jovens também, sei lá, os garotos, às vezes até têm meninas que pensam em ter um namoro sério. Só que a gente percebe que aí os garotos não levam a sério e acabam magoando as meninas. Talvez eles não demonstrem que gostam delas.

De maneira geral, os jovens constatam e projetam um retardamento dos casamentos na medida em que se sucedem as gerações na agricultura familiar, fato que se explica por sua busca de ampliação das experiências afetivas, particularmente no campo da sexualidade, ainda que os controles interpessoais permaneçam. Nesse sentido,

antigamente o meu pessoal, minha avó, eu não tenho bem certeza, mas ela casou com 15,

${ }^{14}$ BOURDIEU, 1999. 
16 anos. Estes anos atrás, as meninadas casavam com 15, 16. Agora, chegou um tempo era 18, 19 anos. Agora o pessoal não tem a cabeça neste negócio de casamento. Por enquanto, é 24, 30. Acho que foi uma coisa que, casamento em si no geral, foi uma coisa que o pessoal não está dando tanto valor assim, cedo, né? (rapaz de Linha Bonita).

Assim, as mudanças sociais e econômicas em curso no espaço rural, o questionamento dos padrões matrimoniais na agricultura familiar e a troca de informações e experiências com os jovens que passam a residir na cidade introduzem novas representações, conceitos e expectativas no horizonte dos jovens, colocando para muitos deles, em primeiro plano, a vontade (e, para muitos, a necessidade) de realizar projetos de vida na cidade e o desejo de experimentar diferentes possibilidades nos relacionamentos afetivos, ficando para depois a concretização de outras dimensões que integram a sua vida pessoal, particularmente o casamento e a família.

No caso das moças, especificamente, alguns relatos indicam que

hoje elas têm outra visão. Naquela época as moças que não namoravam cedo tinham medo de ficar 'encalhada'. Hoje elas não querem mais nenhum compromisso sério. Preferem ficar encalhada (moça de Linha Bonita).

Já para um jovem desta mesma comunidade, hoje residindo na cidade,

construir família e você pensar "poxa, eu poderia ter aproveitado a minha vida e por que eu fui casar tão cedo"? Então tem que aproveitar o que pode, o máximo, tentar construir uma vida melhor, né? Para depois... O casamento se tornou uma coisa secundária, no meu ponto de vista.

De outro ângulo, nas propriedades mais 'estruturadas', há casos em que

se casa mais jovem, mais novo, já constitui sua família para começar a desenvolver aquilo que ele tem interesse. Agora os que saem não acredito que eles casem muito novo não, mais é aqueles que permanecem...

e necessitam dar continuidade ao processo produtivo em curso na propriedade, o que demanda um sucessor capaz de reproduzir o patrimônio da família.

O acesso à educação se constitui em um verdadeiro 'divisor de águas' matrimoniais, pelas oportunidades (profissionais e afetivas) que se ampliam na vida de quem decide pelo ou usufrui o privilégio de ser escolhido para dar continuidade aos estudos. Esse é um diferencial que passa a balizar, também, o perfil do(s) pretendente(s) a contrair núpcias. No caso das moças 'estudadas' ou que se orientam para tal finalidade, elas começam a desenhar um conceito restritivo aos quadros masculinos que integram a agricultura familiar, exceto alguns rapazes que possuem um colorido especial, particularmente aqueles que são grandes candidatos a assumir o gerenciamento de propriedades bem 'estruturadas'. Mas isso

depende bastante. Ainda tem moça que não estudaram e tal, estas que moram no interior às vezes acontece, tem muitos casos que casam o pessoal do interior mesmo lá, o pessoal da comunidade. Mas as moças que vêm para a cidade para estudar ela já põe na cabeça que não quer mais voltar para o interior (rapaz de Linha Bonita).

Para quem avança degraus importantes nos bancos das escolas, ou mesmo (re)constrói as relações sociais cotidianas, conclui:

eu acho que a mulher, a moça tá vendo, porque a partir do momento que você tem uma condição de cultura maior você observa as coisas. Até mesmo quem não tem, vamos supor, a gente vê, né? Então a mulher pensa assim: "ah, adianta também ficar ali, casar, para 
depois ter uma vida destas?" É melhor daí, por exemplo, ir lá pra cidade ganhar um salariozinho e viver lá do que casar praticamente e ficar no interior... Nem que fique sozinha (moça de Linha Pinheiro Alto).

Dados fornecidos pela ONU, para 1995, mostram que, no mundo todo, a correlação entre maior escolaridade e casamento mais tardio por parte das mulheres é uma constante. As que estudam casam-se com mais idade do que as que não estudam, ou freqüentam menos anos de escola; têm menos filhos e usam mais os métodos anticoncepcionais.

Surge uma curiosidade: o que exatamente elas percebem nelas mesmas ou naqueles que compartilham os seus territórios e que resulta em representações questionadoras da sua condição social no espaço rural, de maneira geral, e na agricultura familiar, em especial? As moças começam a responder dizendo que

eu acho que é porque ela no interior, que nem às vezes eu penso assim, não tem fim de semana, né? Você tem que tirar leite de vaca, tem que tratar frango, tem que cuidar. Você não pode deixar a tua propriedade, sair e se divertir e não se preocupar. Você tem que retornar, e daí muitas vezes se teu marido sai você é obrigado a ficar porque tem no caso aviário, chiqueiro, estas coisas. Você é obrigado a ficar porque daí quem que vai ficar pra cuidar? Daí geralmente os homens saem.

Como em um coro,

as vizinhas mesmo da gente comentam aqui que o marido sai, vai lá, joga o futebol dele, vai fazer outras atividades, e elas ficam em casa, praticamente cuidando de todo o trabalho. Então eu penso: "que vida elas têm?" Vão passar a vida delas fazendo só isso! Então a gente fica meio... pensando... (moça de Linha Pinheiro Alto).

Para um determinado padrão de família, em que os jovens alcançam um espaço maior no gerenciamento das atividades produtivas ou mesmo recebem uma retribuição pelo trabalho desenvolvido, a vida de solteiro/a pode ser utilizada como uma referência do que é ou passa a ser a vida da mulher no casamento.

Até que você está na casa do seu pai, da sua mãe é diferente, aí você tem voz e vez. Em determinados casos, aqui no nosso caso é assim. Mas quando você passa para uma outra família talvez seja diferente. Porque aí talvez você não tenha aquela convivência que a gente tem aqui, na nossa família (moça de Linha Bonita).

Ou, a partir de uma construção simples e direta,

depois que você casou, você pode dizer até que você pôs o pé na cova, porque você não sai mais. O teu marido não te chama mais para sair, para ir num matinê, para ir, talvez a mulher gostaria de ganhar um presente ou de sair para jantar, né? Várias coisas, sair para matinê (moça de Linha Pinheiro Alto).

O futebol é invariavelmente o terreno privilegiado do lazer masculino nas comunidades rurais, realizado em um campo (que não se constitui apenas em um 'gramado' natural mas, também, em um fértil ambiente cultural) em que se travam os jogos que atraem as atenções dessas populações e, mais recentemente, o interesse e o olhar crítico feminino. Houve uma época em que as mulheres estavam 'acostumadas' a serem meras expectadoras dos espetáculos realizados pelos jogadores, particularmente nos domingos de torneios envolvendo várias comunidades, comumente animados por 'matinês' (espécie de baile realizado geralmente nos domingos à tarde). Em tais oportunidades, não havia distinção de gêneros; ao contrário, a presença feminina sempre era bem-vinda.

Atualmente, as moças assumem duas posturas em relação ao território alheio: procuram conquistar o seu espaço 'por dentro' dessa manifestação lúdica, praticando e 
constituindo equipes, ou buscam questionar 'por fora' das quadras esportivas o espaço e o tempo potencialmente perdidos, pela presença regular de seus parceiros (namorados, noivos, maridos, etc.) nesses eventos, e passíveis de serem oportunizados e expressos em campos diversos, formados pelas expectativas e desejos femininos. Vejamos como elas observam esse jogo que passa a ser motivo de disputas matrimoniais:

ele vai jogar futebol, que é o gosto dele mas que não é o gosto da mulher. A mulher tem outros planos, ela gosta de outras coisas. Eu até tava falando estes dias, às vezes, a gente, no caso, se sacrifica para ir lá num jogo de futebol. Tudo bem, vamos juntos, tal. Mas agora chega uma hora que sacrifica você também no caso, vai se sacrificar também se você não gosta de matinê. Tem a comida que eu gosto, só que às vezes não acontece isso, este que é o problema também (moça de linha Pinheiro Alto).

Como todo jogo de futebol, nem sempre os resultados são favoráveis, sobretudo para quem não participa, pois

aí o maridão chega cansado do futebol, não tá nem aí pra mulher. A mulher fica em casa o dia inteiro, já fez o serviço dela que todo domingo tem, e aí você fica meio que jogada para escanteio. Porque ele tem o futebol, e tal, mas aí ele não deixa, e é esta a questão, de deixar num domingo o futebol e levar ela para um lugar diferente. Mas aí eles dizem "ah, você pode ir na casa das vizinhas". Mas que graça tem em ir na casa da vizinha? Grande programa ir na casa da vizinha!!! (moça de Linha Pinheiro Alto).

O desejo de ver realizada uma igualdade de direitos, bem como a expectativa de ter acesso aos direitos de cidadania conquistados pelos grupos sociais urbanos, impulsionados e difundidos pelos movimentos sociais rurais e, particularmente, pelo movimento de mulheres agricultoras (MMA), passam a se fazer presente nas representações e nas reivindicações dos jovens. Porém, não há só passividade; já há um começo de reação. As mulheres do MMA, quando se pergunta como os maridos reagem a sua maior independência, dizem que eles percebem que elas ficam 'mais companheiras' e podem gostar (pesquisa realizada no grupo Agricultura Familiar - Reestruturação Social e Capacitação Humana, vinculado ao núcleo de estudos e pesquisas sobre a agricultura familiar da UFSC).

Nesse rol de aspirações, além da vontade e necessidade de ver seus problemas estruturais resolvidos (terra para trabalhar e viver, valorização e remuneração 'justa' dos produtos agrícolas, acesso a assistência técnica, emprego, educação, saúde, entre outros), uma maior participação no gerenciamento das atividades da propriedade e nos 'destinos' do patrimônio familiar, o tempo livre, as férias, os lazeres alternativos, a liberdade, sobretudo a financeira, adquirem uma importância especial pelo simples fato de passar a constituir uma queixa geral entre os jovens, como é o caso de uma moça de Linha Pinheiro Baixo:

aí chega lá no fim do ano, tira lá uns dois dias, vai levar tua mulher para tirar umas férias lá no litoral, não precisa muito! Dois dias chega! Tem alguém que cuida da tua propriedade nestes dois dias, mas leva ela! E eles: "não, eu não gosto de ir lá pro litoral". Mas e aí, e eu? Faço o quê da minha vida? Passo a vida inteira em função do, vamos dizer assim, do marido?

Quanto ao dinheiro, especificamente, uma moça explica qual é o motivo de sua preocupação: "é exatamente isso: a falta de você não ter o teu dinheiro para você fazer o que você quiser". Ancorando sua representação no que significa a oportunidade de possuir um emprego na cidade, esta mesma moça conta o caso de quem vai para a cidade:

aí você vai ter o seu emprego, você vai ter o seu dinheiro, vai ser teu e você vai dizer: "isso eu faço o que eu quero". Vai ajudar o marido, mas tem aquela partezinha que é dela e pronto. 
No entanto, mesmo com toda a liberdade que o emprego e o dinheiro possa representar, percebe-se que essas conquistas arrastam no seu âmago, ainda, o conceito de 'ajuda' ao marido, que certamente não é estranho ao seu cotidiano, constantemente 'martelado' por representações construídas nessa direção. De acordo com Bourdieu, ${ }^{15}$ possuir um maior capital cultural não basta por si só para dar acesso às condições de uma verdadeira autonomia econômica e cultural em relação aos homens. A independência econômica, condição necessária, não é suficiente por si mesma para permitir que a mulher se livre das pressões do modelo dominante, que pode continuar a povoar os habitus masculinos e femininos.

Sempre 'ajudando', desde crianças, a família e os pais, é na concretização dos laços matrimoniais que os apertos se sucedem, pois

a partir do casamento eu acho que fica mais difícil, porque aí já tem aquela questão do marido mandar no dinheiro, tal, e daí a mulher, se ela ainda tiver a sorte de casar com alguém que entenda o lado dela e que tenha, por exemplo, um trabalho específico pra ela e o dinheiro específico daquilo que ela vai ganhar pra ela, então fica mais fácil. Mas tem família, tem casos que não é bem assim (moça de Linha Bonita).

Os dados de pesquisas realizadas na região Oeste de Santa Catarina demonstram a existência, ainda, de uma débil participação dos jovens no processo decisório da agricultura familiar e, particularmente, um viés de gênero presente nessas questões, em prejuízo das moças. Embora esse fato seja registrado com clareza nos segmentos mais pobres, também existe nas propriedades mais 'capitalizadas'. Segundo os pesquisadores do Centro de Pesquisa da Agricultura Familiar (Cepaf) da Empresa de Pesquisa Agrícola e Extensão Rural de Santa Catarina (Epagri), ${ }^{16}$ a sua não-participação nas discussões sobre o futuro da propriedade explica a pouca atração que, em geral, as moças têm pelo trabalho na agricultura. Esses pesquisadores indicam que esse comportamento dos jovens é resultante de, pelo menos, duas razões (sem levar em conta seu maior preparo educacional para enfrentar o mercado de trabalho urbano): ausência de espaço de participação na propriedade e seu desinteresse pela agropecuária em função da penosidade do trabalho. Sugerem que nesta última razão resida a explicação da preferência, por parte de algumas moças entrevistadas, em casar com rapazes de fora do meio rural.

Diversos depoimentos indicam que as moças que saem para estudar não regressam mais às comunidades rurais e que elas, ao buscar os estudos, recusam o casamento com os filhos de agricultores porque isso representa a continuidade da condição social da mulher na agricultura, condição vivida por suas mães e que elas não pretendem reproduzir. Confirmando dados de pesquisas na região Oeste, constata-se, entre os entrevistados, a maior escolaridade das moças em relação aos rapazes. Estes, em sua maioria, projetam o futuro na agricultura, enquanto as moças, refletindo o seu descontentamento nesse meio, sonham com outras perspectivas profissionais, particularmente vinculadas à cidade.

As representações construídas para explicar esse fenômeno adquirem uma ampla gama de variações entre os diferentes gêneros e gerações integrantes da agricultura familiar. Uns salientam suas diferenças, afirmando que "a gente discorda com a mãe nesta questão, a mulher é muito submissa aqui ainda". Nesse caso, elas deixam claro que

eu tenho uma visão totalmente diferente. Eu acho que a mulher tem que batalhar, tem que ter um espaço pra ela, que tá faltando. Eu vejo isso, eu não sou cega, né? Que a mulher aqui é totalmente submissa.

${ }^{15}$ BOURDIEU, 1999, p. 127.

${ }^{16}$ EPAGRI, 2001. 
Ou, sugerindo a necessidade de a mulher marcar presença nos relacionamentos,

eu acho que vai também um pouco da mulher, o dia que ela for pensar em ter um relacionamento, já colocar pra ele "ó, eu quero, eu posso até casar, mas eu tenho as minhas idéias, penso nisso", enfim, colocar pro cara que você tá aí, pra pessoa que você tá aí, e você pensa assim e vai ser assim. Talvez um pouco disso, também.

$\mathrm{E}$, finalmente, uma constatação recorrente e um alerta, em forma de 'pulga atrás da orelha', para os rapazes que visualizam o casamento e a permanência na agricultura:

elas não gostam de trabalhar na roça. Olha, qual moça que procura um rapaz pra casar que trabalha na roça? Elas não gostam de trabalhar na roça, preferem mais estudar, preferem mais outros empregos, porque na colônia hoje em dia não dá mais nada (mulher agricultora de Linha Bonita).

E o que pensam os rapazes a respeito?

Eu acho que é difícil porque as moças não gostam muito do interior, porque tem que trabalhar mais e na cidade sempre é melhor, né. Você tem uma condição de vida bem melhor na cidade do que ficar no interior trabalhando. Tem umas que ainda ficam. A maioria, quem estuda, gostaria mais de ir para a cidade do que ficar no interior (rapaz de Linha Pinheiro Alto).

Este mesmo jovem conta que "tinha uma namorada. Namorei até um tempo, depois ela saiu para ir para a cidade também. Não namoro mais". Para as mulheres, "interior ou cidade' não constitui apenas opções de moradia; está em jogo a relação entre 'independência e dependência'. Não é pela cidade em si que elas saem, ou exclusivamente pela procura de uma melhor condição de vida, mas, sobretudo, pela independência que isso pode proporcionar.

No intuito de justificar os motivos da presença de uma 'inclinação urbana' no imaginário das filhas de agricultores familiares, alguns jovens traçam nas suas representações um paralelo entre os diferentes espaços da sociedade, abordando noções vinculadas à estética, ao corpo, aos costumes, ao consumo, entre outros aspectos. As circunstâncias como são realizados os processos produtivos na agricultura, que ainda necessitam avançar bastante na direção dos padrões 'humanitários' de trabalho e de remuneração dos esforços despendidos, são destacadas pelas moças entre os fatores que inferiorizam a imagem daqueles/as que são do interior, em benefício dos conceitos, valores e símbolos da cidade. Trata-se das razões que refletem suas escolhas afetivas.

É mais difícil assim para um rapaz encontrar uma moça que queira ficar no interior. As moças elas querem estar mais bem vestidas, estar mais perfumadinha, e aqui a gente não pode ter isso, porque a gente trabalha o dia inteiro, e muitas vezes a gente não tem o tempo, a gente trabalha na terra, a gente trabalha com animais, a gente sempre não pode estar tão legal, bem vestido como você pode estar na cidade, e é lógico que as meninas da cidade sempre têm mais condições de ficar melhor e tal. Então acho que às vezes elas pensam muito nisso e talvez seja por isso, eu acho que grande parte desta saída das moças, deste interesse mais pelo pessoal da cidade é por causa disso, uma vida mais sossegada" (moça de Linha Vitória).

O que leva esses/as filhos/as de agricultores familiares a redefinirem seus planos originais? Quem são as moças da cidade que casam com rapazes do interior?

As 'luzes da cidade' nem sempre iluminam os planos de todos os que aí projetam os seus horizontes profissionais, as expectativas educacionais e os desejos de 'mudar' de vida. Os relatos informando o retorno de alguns jovens (particularmente rapazes), embora ainda em número reduzido, bem como as precárias condições de emprego, ilustram esse fato. Embora ainda tenham um caráter excepcional, há casos, como sugerem os próprios depoimentos, que 
Tem uns garotos até que casou com umas meninas da cidade. Eu achei bem interessante assim porque elas saírem de lá para vim pra cá, não sei como que aconteceu isso porque é muito difícil, é muito raro a gente vê, né? E tem um monte de rapazes também que não namoram, não conseguem namorar por causa disso. Tem uns que não se interessam por namorar, mas tem uns rapazes que acham super difícil mesmo. As meninas elas querem estudar, querem sair, fazer faculdade, e os garotos do interior está muito difícil para eles encontrarem namorada, é bem complexo mesmo este tema" (moça de Linha Pinheiro Alto).

Diante da constatação de que esse fato começa a se tornar um problema para os rapazes que vivem nas comunidades rurais, em que "está preocupante a situação porque eu disse assim os rapazes não vão querer ficar na colônia para passar a vida deles sozinhos, né, ninguém está a fim", as decisões adquirem algumas peculiaridades. A partir da decisão de não ficar só, os caminhos e as estratégias se cruzam nos planos desses jovens. Duas vias que aparecem nas entrevistas comumente vêm sendo utilizadas. A primeira implica a procura de um projeto de vida alternativo na cidade; a segunda, ainda rara, representa os casos em que os filhos de agricultores, visando ao casamento e à constituição de uma família, buscam as moças na cidade.

No primeiro caso, de maneira geral, o fato de eles optarem por sair cria as condições para que casamento e família se 'encontrem' a partir da cidade:

eles não vão ficar, eu penso assim, eles não vão ficar no interior, nem que eles vão na cidade. Tem o emprego de passar fome mas eles vão na cidade, pelo menos eles vão ter uma condição de constituir uma família, porque senão eles não vão estar a fim de ficar no interior para passar a vida deles praticamente na solidão (moça de Linha Pinheiro Alto).

Com a maior tendência das moças em buscar novos rumos, em muitos casos, 'impulsionadas' pelos próprios pais, essas iniciativas femininas acabam 'arrastando' rapazes com que mantinham algum tipo de laço afetivo antes (ou mesmo depois) de elas tomarem sua decisão, fazendo com que "o namorado da minha irmã era daqui e foi para a cidade. Ela foi e ele foi também. A irmã dele também vai querer sair agora. Ele está dirigindo caminhão para uma agropecuária" (moça de Linha Pinheiro Alto). "E todo mundo disse: "ah, porque ele saiu..., culpa tua, porque você quis morar na cidade e você não quis voltar, daí ele saiu também'" (moça de Linha Mazziero).

Quanto ao fato do apoio caseiro para a elaboração de estratégias visando à saída, os próprios jovens comentam que

se não mudar um pouco a mentalidade dos pais, até de incentivarem os filhos a ficar, até as moças, tentar assim incentivar, porque o problema do agricultor é o seguinte: é que eles incentivam muito as filhas a irem para a cidade. Mas então quem que vai casar com os filhos deles? Eles não tão preocupados com esta ideologia (moça de Linha Pinheiro Alto).

No segundo caso, apesar de toda a excepcionalidade do fenômeno, cabe registrálo por seu caráter simbólico e pelo fato de indicar a existência de uma redefinição na noção tradicional de casamento na agricultura familiar. O mercado (matrimonial) citadino chega ao interior, pois

teve uns que casaram com moças da cidade também, os rapazes daqui, que daí elas eram da cidade tal, só que tinham uma condição não muito boa, daí eles casaram, trouxeram elas para morar no interior.

Esta última observação do depoimento indica também a presença de um recorte econômico nesse mercado, explicitado pelas próprias moças que sugerem:

está mais fácil de certas meninas da cidade com condições baixas vir morar no interior do 
que as próprias meninas que vivem no interior ficarem no interior, porque elas terminam o segundo grau e já querem fazer faculdade, mas não pensando para um dia voltar, né? É para um dia ficarem mesmo, elas não pensam em retornarem (moça de Linha Pinheiro Baixo).

A existência de uma maior flexibilidade nas decisões relativas ao casamento, em que os jovens não assumem um papel tão passivo como outrora, não implica afirmar que as escolhas dos parceiros desconsiderem totalmente os atrativos e os interesses econômicos resultantes da união das famílias. Nessa perspectiva, nos casos em que os filhos de agricultores são os candidatos a herdarem o patrimônio 'estruturado' da família, criam-se condições favoráveis para que as moças da cidade (que, em muitos casos, são oriundas do interior) aceitem esse 'convite' de casamento.

Assim, diferentemente daqueles que têm planos de sair e deixar o casamento e a família para depois, verifica-se existirem nas comunidades rapazes que

eu não sei o porquê que não namoram, eu acho que porque são os únicos filhos que ficaram para cuidar dos pais. Tem as irmãs, mas como sempre a família italiana sempre pende pro lado masculino, né, então quem é o herdeiro sempre é o menino, nunca a menina (moça de Linha Bonita).

Ou:

É porque aqui na comunidade, ó, tem algum rapaz já que tá sem namorada, 22, 23, 25, 27 anos. Quase todos têm que, que nem, administrar a propriedade já, né, e daí têm que ficar na roça. Se é para ir na cidade, vamos supor, tem que vender tudo, né, a propriedade, não tem outros que toquem [...] O meu plano era de casar e ficar no interior, continuar que nem os pais, né, mas pra arrumar uma moça pra casar... (rapaz de Linha Pinheiro Alto).

Como elas mesmo afirmam, porém, as mulheres sonham mais alto. E ficar com a família pode significar a não-concretização de seus ideais, pois "a maioria das moças sentem que ficar sempre lá debaixo da asa do pai e da mãe não vai ter outra solução senão você casar com alguém ali da comunidade mesmo". Mesmo que as palavras e as expectativas não fluam tão facilmente, porque influenciadas pela maré dos padrões culturais que as arrastam, como uma rede, para outra direção, elas expressam finalmente o rumo diferenciado dos seus sentimentos:

Não que não seja válido, né? Mas assim, casar e ficar por ali mesmo, sem ter... eu acho que as moças têm mais esta visão de querer mais. Acho que valorizam mais os seus sonhos, sonham mais alto. Os rapazes não, por eles tá bom por ali mesmo, eu sinto um pouco isso (moça de Linha Pinheiro Baixo).

\section{Considerações finais}

No âmbito da (re)construção conceitual das instituições do casamento e da família na agricultura familiar, percebe-se, a partir das representações e iniciativas dos jovens, que as suas situações são de contradição, pois se deparam com valores conflitivos no horizonte das escolhas, pressionados por uma condição social caracterizada pela complexidade dos problemas enfrentados. Nesse cenário, as escolhas dos modelos de família e casamento nem sempre são compartilhadas pelos parceiros, particularmente aqueles que passam a exigir 'algo mais' nos relacionamentos afetivos ou nas suas vidas. Esse fato torna-se um agravante para os filhos de agricultores familiares; embora suas implicações alcancem principalmente aqueles que não visualizam um futuro promissor no âmbito de uma propriedade agrícola, não deixa de abalar, também, o mercado matrimonial dos jovens capitalizados. 
Assim, se o casamento, tradicionalmente, assumia um papel fundamental na reprodução social do patrimônio familiar e na organização do processo de trabalho, buscar reproduzi-lo com modelos e padrões típicos de família, de pai, passa a ser questionável para parcela significativa de moças descontentes com o papel e o lugar a elas atribuído nesse processo. Enfim, atualmente, na agricultura familiar, o sonho de receber um 'sim' em uma cerimônia matrimonial é precedido de muitas interrogações, levantadas sobretudo pelas moças 'acostumadas' a receber um 'não' na sua realidade cotidiana, como contrapartida do papel e do lugar que ocupam (ou que desejam conquistar) na família, na comunidade e na sociedade.

\section{Referências bibliográficas}

ABRAMOVAY, Ricardo. "Uma nova extensão para a agricultura familiar". In: SEMINÁRIO NACIONAL DE ASSISTÊNCIA TÉCNICA E EXTENSÃO RURAL, 1997, Brasília. Texto para discussão, 29. 1997a.

ABRAMOVAY, Ricardo et al. Juventude e agricultura familiar: desafios dos novos padrões sucessórios. Chapecó/Brasília: FAO/INCRA/EPAGRI-SC/Centro de Pesquisa para Pequena Propriedade, 1997b.

BOURDIEU, Pierre. "Célibat et condition paysanne". Etudes Rurales, n. 5-6, p. 32-135, avril/ sept. 1962.

BOURDIEU, Pierre. Lá distinction: critique sociale du jugement. Paris: Les Èditions de Minuit, 1979.

BOURDIEU, Pierre. A dominação masculina. Rio de Janeiro: Ed. Bertrand Brasil, 1999.

CEPAL. Desarollo rural sin jóvenes? LC/R. 1.599, Santiago, 1995. Mimeo.

CEPAL - DIVISION DE DESAROLLO SOCIAL. "Juventud rural: fuerza de modernidad y democracia". In: CEPAL. Juventud rural: modernidad y democracia en América Latina. Santiago do Chile, 1996.

EPAGRI. Os impasses sociais da sucessão hereditária na agricultura familiar. Chapecó: Cepaf, 2001.

GALESKI, Branislaw. Basic Concepts of Rural Society. Manchester: Manchester University Press, 1975.

PAULILO, Maria Ignez Silveira. "Movimento de mulheres agricultoras: terra e matrimônio". Cadernos de Pesquisa, Florianópolis: UFSC, n. 21, p. 1-17, jun. 2000.

ROUX, Bernard. L'économie de l'agriculture. Paris: Éditions Clartés, 1998.

SIQUEIRA, Deise. "A organização das mulheres trabalhadoras rurais: o cruzamento de gênero e de classe social". In: TEIXEIRA, João Gabriel (Org.) Tecnologia agropecuária e a organização dos trabalhadores rurais. Brasília: Ed. da UnB, 1992. p. 57-89.

STROPASOLAS, Valmir Luiz. O mundo rural no horizonte dos jovens: o caso dos filhos(as) de agricultores familiares de Ouro/SC. 2002. Tese (Doutorado Interdisciplinar em Ciências Humanas) - Universidade Federal de Santa Catarina, Florianópolis.

TEIXEIRA, Zuleide Araújo et al. (Org.). Perspectivas de gênero na produção rural. Brasília: IPEA, 1994. (Estudos de política agrícola, 22).

WOORTMANN, Ellen. Herdeiros, parentes e compadres: colonos do Sul e sitiantes do Nordeste. Brasília: EdUnb; São Paulo: Hucitec, 1995.

The Value of Marriage to the Farm Family

Abstract: This article concerns the questioning of cultural values among farm families and specifically presents various representations that have been constructed by young people and women about the notion of marriage. To discuss the meaning, importance and the redefinitions currently being established about the category of marriage, an analysis was conducted of the 
statements of the sons and daughters of farm families collected during my doctoral research in western Santa Catarina state. Based on the analysis of the representations and actions of rural youth, an emergence of conflicts was identified concerning the choice of family models and marriage. This has influenced the life plans made by young men and women and gives importance to the factor of gender in the migratory movement of youth.

Key words: farm family, youth, gender, marriage. 